\title{
Half Maximal Inhibitory Concentration Reference Control Result Measurement
}

National Cancer Institute

\section{Source}

National Cancer Institute. Half Maximal Inhibitory Concentration Reference Control

Result Measurement. NCI Thesaurus. Code C116248.

A reference control sample response based on a concentration of a specific drug expected to produce $50 \%$ inhibition of the standard growth of a viral organism, or of a biological/biochemical reaction. 